\title{
INFLUENCE OF TILLAGE METHODS ON OPTIMIZATION OF NUTRITION, YIELD AND FILLING GRAIN OF WINTER WHEAT ON LEACHED CHERNOZEM
}

\author{
Sergey Korostylev, Alexander Esaulko, Alena Ozheredova, Natalya Gromova, Yuliya Grechishkina \\ Stavropol State Agrarian University, Russia \\ korostylev16@mail.ru, aesaulko@yandex.ru, alena.gurueva@mail.ru,nikolenko0812@mail.ru, \\ lnwg@mail.ru
}

\begin{abstract}
Based on the conducted research, experimental data were obtained that allowed recommending a calculation and balance method for determining fertilizer rates for constructing a fertilizer calculation system, which allowed obtaining the maximum yield of winter wheat $\left(6.01 \mathrm{t} \cdot \mathrm{ha}^{-1}\right)$ after the forecrop peas on leached chernozem. The optimal combination of systems for fertilizing winter wheat after its forecrop peas with methods and techniques for placing mineral fertilizer in a $0-20 \mathrm{~cm}$ soil layer has been established.Obtaining high and stable yields with good quality of grain production of winter wheat, preservation and improvement of soil fertility, improvement of economic indicators in farms is impossible without the use of a rationally composed fertilizer system. It implies a reduction in doses of fertilizers, an increase in soil stocks of nutrients. Modern fertilizer systems should be based on biologicalization of agriculture, combined with the rational use of mineral and organic fertilizers, in relation to specific soil-climatic and economic conditions, taking into account the requirements of ecology and adaptive farming. Different methods and techniques of tillage affect its structural state, the structure of the arable layer, water-air, nutrient and thermal regimes, thereby affecting the growth conditions of plants, which affects their productivity.The main objective of the research was to determine the influence of fertilizer systems, methods and techniques of tillage on the food regime of leached chernozem and the productivity of winter wheat.The studies were carried out in an experimental crop rotation of the permanent study area located at the experimental station of the Stavropol State Agrarian University. The station is a longterm experience "Theoretical and technological bases of biogeochemical flows of substances in agrolandscapes", registered in the certificates record of long-term experiments of the GeoNetwork of the All-Russian Scientific Research Institute of Agrochemistry of the Russian Federation.
\end{abstract}

Keywords: method of tillage, yield, winter wheat, leached chernozem.

\section{Introduction}

Winter wheat yield and quality are determined by a host of environmental factors; however, the high grain yield and quality can be achieved only by maximally approximating crop growth, development, wintering, nutrition, yield structural elements' formation and other conditions, varying in relation to natural-climatic factors, soil peculiarities, agronomic practices applied or crop cultivation technologies to optimal ones. The quality of winter wheat yield depends on physiological-biochemical processes, which occur in plants during ontogenesis [1].

Obtaining high and stable yields with good quality of grain production of winter wheat, preservation and improvement of soil fertility, improvement of economic indicators in farms is impossible without the use of a rationally composed fertilizer system. It implies a reduction in doses of fertilizers, an increase in soil stocks of nutrients. Modern fertilizer systems should be based on biologicalization of agriculture, combined with the rational use of mineral and organic fertilizers, in relation to specific soil-climatic and economic conditions, taking into account the requirements of ecology and adaptive farming. Different methods and techniques of tillage affect its structural state, the structure of the arable layer, water-air, nutrient and thermal regimes, thereby affecting the growth conditions of plants, which affects their productivity [2].

The main agrotechnical method of increasing soil fertility and crop productivity is a rationally composed fertilizer system, taking into account the bioclimatic potential of the area (zone), plant characteristics and market conditions. Soil fertilizer performs not only the functions of replenishment of nutrients for plants, but also their mobilization in the soil in an accessible form, increasing the energy of life processes in the soil, improving their properties. Consequently, a scientifically based fertilizer system performs important ecological functions when applied in the agroecosystem. It is most effective to use fertilizers in crop rotation. Only rational use of agrochemical agents will preserve and maintain high soil fertility [3].

Balanced nutrition of plants with macronutrients and microelements controls numerous metabolic processes and plays a key role in the formation of the crop and its chemical composition. All nutrients 
perform vital functions in the plant. Their content determines the productivity of crops, the shortage of nutrients will certainly affect the yield and quality of products. Plants are almost indifferent to what is the source of nutrients - the solid phase of the soil or fertilizer. It is important that they are in the soil in sufficient quantity and optimal ratio. At any level of chemicalization of agriculture it is necessary to control the state of the balance of nutrients in the system "soil-plant" [4;5].

Stavropol Territory maintains the position of one of the largest grain-producing regions in Russia and a supplier of high-quality grain. However, obtaining high and stable yields with good quality of grain production of winter wheat, preservation and improvement of soil fertility, improvement of economic indicators in farms is impossible without the use of a rationally compiled fertilizer system. It implies a reduction in doses of fertilizers, an increase in soil stocks of nutrients.

Modern fertilizer systems should be based on biologicalization of agriculture, combined with the rational use of mineral and organic fertilizers, in relation to specific soil-climatic and economic conditions, taking into account the requirements of ecology and adaptive farming. Different methods and techniques of tillage affect its structural state, the structure of the arable layer, water-air, nutrient and thermal regimes, thereby affecting the growth conditions of plants, which affects their productivity [6;7].

\section{Materials and methods}

The main objective of the research was to determine the influence of fertilizer systems, methods and techniques of tillage on the nutrient regime of leached chernozem and the productivity of winter wheat.

The objectives of the research included:

- to study the effect of fertilizer systems, methods and techniques of tillage on the dynamics of agrochemical indicators $0-20 \mathrm{~cm}$ of the leached chernozem layer during the growth and development of winter wheat;

- to determine the effect of the methods studied in the experiment on the yield and qualitative characteristics of winter wheat grain.

Researches were conducted in 2010-2014 in the experimental crop rotation of the permanent study arealocated at the experimental station of the Stavropol State Agrarian University. The station department is a long-term experience "Theoretical and technological bases of biogeochemical flows of substances in agrolandscapes", registered in the certificates record of long-term experiments of the GeoNetwork of the All-Russian Scientific Research Institute of Agrochemistry of the Russian Federation. It was founded by the staff of the Department of Agricultural Chemistry and Agriculture of the Stavropol State Agrarian University in 1976.

The soil of the experimental plot is leached chernozem, powerful, slightly humus, heavy-loam. It is characterized by average values of humus content (5.2-5.9\%), mobile phosphorus $\left(22-28 \mathrm{mg} \cdot \mathrm{kg}^{-1}\right)$ and exchangeable potassium $\left(240-290 \mathrm{mg} \cdot \mathrm{kg}^{-1}\right)$. The nitrification capacity of the soil is increased - 16$30 \mathrm{mg} \cdot \mathrm{kg}^{-1}$. The reaction of the soil solution is neutral $-6.1-6.7$ units. In the experiment, a zoned variety of winter wheat Zustrich was studied. The forecrop is pea. Fertilizers were used: ammophos, nitroammofosk, ammonium nitrate, potassium chloride. Experience two-factor, $3 \times 4$. Placement of options randomized according to the method of split plots, the repetition of the experiment is 3 times, the plot width is $7.5 \mathrm{~m}$, length is $1 \mathrm{~m}$. The total plot area is 108square meters, and the accounting area is 50square meters [2].

Factor A - methods and techniques of tillage.

The variants with the fertilizer systems studied according to the scheme of experience were superimposed on the variants with various methods and techniques of the main tillage:

1. Moldboard method (mounted plough 5-35), 20-22 cm;

2. Combined method (tillager -6 ), $20-22 \mathrm{~cm}$;

3. Surface tillage (disk tiller $4 \times 4$ ) $10-12 \mathrm{~cm}$.

Factor B - fertilizer system (Table1). 
Winter wheat fertilizer system after its forecrop peas, $\mathrm{kg} \cdot \mathrm{ha}^{-1}$ primary nutrient

\begin{tabular}{|c|c|c|c|c|}
\hline \multirow{2}{*}{ 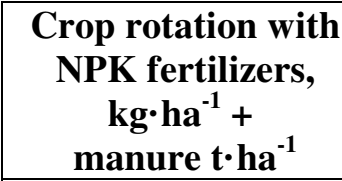 } & \multirow[b]{2}{*}{$\begin{array}{l}\text { Applied directly under } \\
\text { the culture }\end{array}$} & \multicolumn{3}{|c|}{ Fertilizerapplicationmethods } \\
\hline & & Main & At seeding & $\begin{array}{c}\text { Additionalfe } \\
\text { rtilization }\end{array}$ \\
\hline Control & - & - & - & - \\
\hline Recommended & $\mathrm{N}_{70} \mathrm{P}_{40}$ & $\mathrm{~N}_{30} \mathrm{P}_{30}$ & $\mathrm{~N}_{10} \mathrm{P}_{10}$ & $\mathrm{~N}_{30}$ \\
\hline Biologized & straw $2.4 \mathrm{t} \cdot \mathrm{ha}^{-1}+\mathrm{N}_{60} \mathrm{P}_{10}$ & $\begin{array}{c}\text { straw } 2.4 \mathrm{t} \cdot \mathrm{ha}^{-} \\
{ }^{1}+\mathrm{N}_{20}\end{array}$ & $\mathrm{~N}_{10} \mathrm{P}_{10}$ & $\mathrm{~N}_{30}$ \\
\hline Computational & $\mathrm{N}_{120} \mathrm{P}_{75} \mathrm{~K}_{24}$ & $\mathrm{~N}_{60} \mathrm{P}_{65} \mathrm{~K}_{24}$ & $\mathrm{~N}_{10} \mathrm{P}_{10}$ & $\mathrm{~N}_{50}$ \\
\hline
\end{tabular}

During the period of the research, surveys, observations and analyzes were carried out.

In soil samples, the following was determined:

- nitrate nitrogen by the ionometric method using an ion-selective electrode, the State standard GOST 26951-86;

- ammoniacal nitrogen - by colorimetration with Nessler's reagent, the State standard GOST 26489-91;

- mobile phosphorus and exchange potassium according to Machigin in modification of the Central Research Institute of Agrochemical Service of Agriculture, the State standard GOST 26205-91.

In plant samples it was determined:

- yield of winter wheat by the method of mechanized harvesting according to the State measurement system (1983);

- grain quality of winter wheat: protein according to the State standard GOST 10846-91;

- gluten mass fraction - according to the State standard GOST 13586.1;

- vitreous - according to the State standard GOST-10987;

- 1000 grains mass - according to the State standard GOST 10842-89;

- statistical processing of experimental data by correlation-regression and dispersion methods $[8 ; 9]$.

\section{Results and discussion}

The values of mineral nitrogencontent in the variants with the use of the moldboardtillage method turned out to be significantly higher than the combined method and the surface tillage method by 2.6 and $4.8 \mathrm{mg} \cdot \mathrm{kg}^{-1}$ of soil (Table 2).

The maximum content of mineral nitrogen in the $0-20 \mathrm{~cm}$ layer of leached chernozem during the growing season of winter wheat was obtained using the moldboardsoil tillage method- $24.9 \mathrm{mg} \cdot \mathrm{kg}^{-1}$, which is significantly higher $\left(2.6\right.$ and $\left.4.8 \mathrm{mg} \cdot \mathrm{kg}^{-1}\right)$ of the combined method and surface tillage. Fertilizer systems significantly increased the concentration of mineral nitrogen as compared with the control - by $2.2-8.4 \mathrm{mg} \cdot \mathrm{kg}^{-1}$. The highest content of mineral nitrogen in the soil $-25.3 \mathrm{mg} \cdot \mathrm{kg}^{-1}$ was noted in the tilleringstage, and then there was a decrease towards the full ripeness phase.

During the growing season of winter wheat, the content of mobile phosphorus on all variants of the experiment steadily decreased with the achievement of minimum values in the phase of full ripeness. The maximum content of mobile phosphorus, $22.2 \mathrm{mg} \cdot \mathrm{kg}^{-1}$, was noted on the variants using the moldboardsoil tillage method (Table 3).

The use of fertilizers significantly increased the average elemental content in the $0-20 \mathrm{~cm}$ soil layer as compared with the control by $2.2-9.7 \mathrm{mg} \cdot \mathrm{kg}^{-1}$ soil. The content of mobile phosphorus turned out to be higher in the variants with the moldboard soil tillage method as compared with the combined one by 0.7 and $1.7 \mathrm{mg} \cdot \mathrm{kg}^{-1}$ relative to the surface tillage. The maximum content of mobile phosphorus, $25.3 \mathrm{mg} \cdot \mathrm{kg}^{-1}$ of soil, on the variants with the use of all fertilizer systems was noted before the sowing of the crop, then there was a significant decrease with the minimum values in the phase of full ripeness of winter wheat $-17.0 \mathrm{mg} \cdot \mathrm{kg}^{-1}$ of soil. 
Effect of fertilizer systems, techniques and methods of tillage on the dynamics of mineral nitrogen content $\left(\mathrm{mg}^{\cdot \mathrm{kg}^{-1}}\right)$ in the $\mathbf{0 - 2 0} \mathrm{cm}$ soil layer in winter wheat crops

\begin{tabular}{|c|c|c|c|c|c|c|c|c|}
\hline \multirow[b]{2}{*}{$\begin{array}{c}\text { Techniques and methods of } \\
\text { tillage, } \mathrm{A}\end{array}$} & \multirow[b]{2}{*}{$\begin{array}{l}\text { Fertilizersystem, } \\
\text { B }\end{array}$} & \multicolumn{5}{|c|}{ Selectionterm, C } & \multirow[b]{2}{*}{ 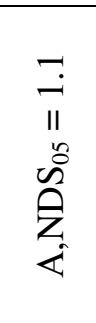 } & \multirow[b]{2}{*}{ 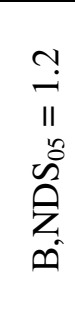 } \\
\hline & &  &  &  & : &  & & \\
\hline \multirow{4}{*}{ Moldboard method, $20-22 \mathrm{~cm}$} & Control & 23.3 & 26.2 & 22.8 & 21.0 & 17.4 & \multirow{4}{*}{24.9} & 18.7 \\
\hline & Recommended & 27.5 & 28.9 & 26.9 & 25.7 & 19.6 & & 22.9 \\
\hline & \begin{tabular}{|l|} 
Biologized \\
\end{tabular} & 23.5 & 25.0 & 24.8 & 23.9 & 18.8 & & 20.9 \\
\hline & Computational & 29.6 & 31.9 & 30.9 & 29.5 & 22.5 & & 27.1 \\
\hline \multirow{4}{*}{ Combined method, $20-22 \mathrm{~cm}$} & Control & 18.1 & 20.1 & 17.9 & 16.5 & 14.4 & \multirow{4}{*}{22.3} & \\
\hline & Recommended & 25.4 & 25.9 & 25.1 & 22.0 & 17.3 & & \\
\hline & Biologized & 22.2 & 22.6 & 21.9 & 21.1 & 16.1 & & \\
\hline & Computational & 29.2 & 31.2 & 30.1 & 26.1 & 22.1 & & \\
\hline \multirow{4}{*}{ Surface tillage, $10-12 \mathrm{~cm}$} & Control & 17.6 & 18.8 & 16.5 & 15.9 & 13.4 & \multirow{4}{*}{20.1} & \\
\hline & Recommended & 21.1 & 22.3 & 21.9 & 20.5 & 15.1 & & \\
\hline & Biologized & 20.1 & 20.9 & 19.4 & 19.3 & 14.5 & & \\
\hline & Computational & 25.2 & 29.9 & 25.1 & 23.3 & 20.2 & & \\
\hline \multicolumn{2}{|c|}{$\mathrm{C}, \mathrm{NDS}_{05}=1.2$} & 23.6 & 25.3 & 23.6 & 22.1 & 17.6 & \multicolumn{2}{|c|}{$\mathrm{NDS}_{05}=3.6$} \\
\hline
\end{tabular}

Table 3

Effect of fertilizer systems, techniques and methods of tillage on the dynamics of mobile phosphorus content $\left(\mathrm{mg} \cdot \mathrm{kg}^{-1}\right)$ in the $0-20 \mathrm{~cm}$ soil layer in winter wheat crops

\begin{tabular}{|c|c|c|c|c|c|c|c|c|}
\hline \multirow[b]{2}{*}{$\begin{array}{l}\text { Techniques and methods of } \\
\text { tillage, A }\end{array}$} & \multirow[b]{2}{*}{$\begin{array}{l}\text { Fertilizersystem, } \\
\text { B }\end{array}$} & \multicolumn{5}{|c|}{ Selectionterm, C } & \multirow[b]{2}{*}{ 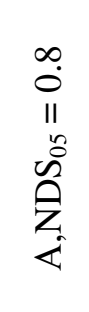 } & \multirow[b]{2}{*}{ 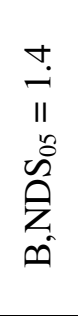 } \\
\hline & & $\begin{array}{l}00 \\
\stackrel{0}{3} \\
0 \\
0 \\
0 \\
0 \\
0 \\
0 \\
0\end{array}$ & & 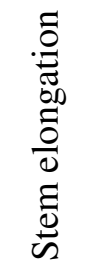 & 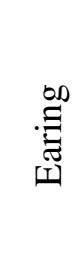 &  & & \\
\hline \multirow{4}{*}{ Moldboard method, $20-22 \mathrm{~cm}$} & Control & 22.7 & 19.9 & 16.2 & 14.4 & 13.5 & \multirow{4}{*}{22.2} & 17.2 \\
\hline & Recommended & 28.3 & 25.8 & 23.5 & 19.7 & 18.2 & & 22.0 \\
\hline & Biologized & 24.8 & 21.7 & 19.8 & 18.4 & 16.9 & & 19.4 \\
\hline & Computational & 32.8 & 31.1 & 28.4 & 25.1 & 23.2 & & 26.9 \\
\hline \multirow{4}{*}{ Combined method, $20-22 \mathrm{~cm}$} & Control & 22.1 & 19.9 & 16.0 & 14.8 & 14.1 & \multirow{4}{*}{21.5} & \\
\hline & Recommended & 27.4 & 25.7 & 21.2 & 19.0 & 16.2 & & \\
\hline & Biologized & 23.2 & 21.7 & 20.1 & 18.1 & 15.5 & & \\
\hline & Computational & 31.1 & 30.2 & 27.1 & 24.1 & 22.1 & & \\
\hline \multirow{4}{*}{ Surface tillage, $10-12 \mathrm{~cm}$} & Control & 21.8 & 19.1 & 15.5 & 13.9 & 13.9 & \multirow{4}{*}{20.5} & \\
\hline & Recommended & 26.3 & 25.1 & 20.1 & 18.5 & 15.5 & & \\
\hline & Biologized & 22.1 & 20.1 & 18.5 & 17.3 & 13.5 & & \\
\hline & Computational & 30.1 & 28.1 & 26.1 & 24.1 & 21.3 & & \\
\hline \multicolumn{2}{|l|}{$\mathrm{C}, \mathrm{NDS}_{05}=1.2$} & 25.3 & 24.0 & 21.0 & 18.9 & 17.0 & NDs & $=3.5$ \\
\hline
\end{tabular}

The combined method and surface treatment of the soil reduced, relative to the moldboard method, the content of exchangeable potassium on average during the growing season by $6-8 \mathrm{mg} \cdot \mathrm{kg}^{-1}$ of soil. On the variants with the use of the moldboard soil tillage method, on average, by experience, the maximum content of exchangeable potassium, $243 \mathrm{mg} \cdot \mathrm{kg}^{-1}$ of soil, was noted (Table 4). 
The use of fertilizers increased the concentration of the element relative to the control by 13$26 \mathrm{mg} \cdot \mathrm{kg}^{-1}$ of soil throughout the growing season of winter wheat. Before sowing winter wheat, the content of the element was $254 \mathrm{mg} \cdot \mathrm{kg}^{-1}$, by the heading stage of the crop the content reached $222 \mathrm{mg} \cdot \mathrm{kg}^{-1}$, and by the full ripeness phase, the concentration of the element increased to $230 \mathrm{mg} \cdot \mathrm{kg}^{-1}$. The maximum content of exchangeable potassium in the soil layer of $0-20 \mathrm{~cm}$ was noted in the variants with biologized and computational fertilizer systems.

All the fertilizer systems studied in the experiment significantly increased the yield of winter wheat, and the difference relative to the control was: on the moldboard method $-1.31-2.23 \mathrm{t} \cdot \mathrm{ha}^{-1}$, combined $-1.14-1.88 \mathrm{t} \cdot \mathrm{ha}^{-1}$, surface treatment $-0.99-1.62 \mathrm{t} \cdot \mathrm{ha}^{-1}$. Surface treatment significantly reduced the crop yield $\left(0.56-0.63 \mathrm{t} \cdot \mathrm{ha}^{-1}\right)$ as compared to the moldboard and combined methods of tillage (Table 5).

Table 4

Effect of fertilizer systems, techniques and methods of tillage on the dynamics of exchangeable potassium $\left(\mathrm{mg} \cdot \mathrm{kg}^{-1}\right)$ in the $0-20 \mathrm{~cm}$ soil layer in winter wheat crops

\begin{tabular}{|c|c|c|c|c|c|c|c|c|}
\hline \multirow[b]{2}{*}{$\begin{array}{l}\text { Techniques and methods of } \\
\text { tillage, A }\end{array}$} & \multirow[b]{2}{*}{$\begin{array}{l}\text { Fertilizersystem, } \\
\text { B }\end{array}$} & \multicolumn{5}{|c|}{ Selectionterm, C } & \multirow[b]{2}{*}{  } & \multirow[b]{2}{*}{ 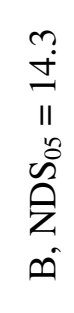 } \\
\hline & & 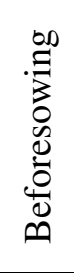 & $\stackrel{\stackrel{\infty}{\Xi}}{\stackrel{\Xi}{\Xi}}$ & 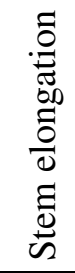 & 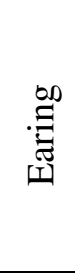 & $\begin{array}{l}\tilde{U} \\
\stackrel{\Xi}{\Xi} \\
\stackrel{\Xi}{\Xi} \\
\bar{\Xi} \\
\bar{\Xi}\end{array}$ & & \\
\hline \multirow{4}{*}{ Moldboard method, $20-22 \mathrm{~cm}$} & Control & 245 & 244 & 230 & 200 & 212 & \multirow{4}{*}{243} & 223 \\
\hline & Recommended & 260 & 259 & 235 & 228 & 230 & & 236 \\
\hline & Biologized & 267 & 265 & 242 & 231 & 239 & & 246 \\
\hline & Computational & 271 & 270 & 250 & 239 & 247 & & 249 \\
\hline \multirow{4}{*}{ Combined method, $20-22 \mathrm{~cm}$} & Control & 243 & 242 & 225 & 196 & 205 & \multirow{4}{*}{237} & \\
\hline & Recommended & 245 & 244 & 232 & 225 & 229 & & \\
\hline & Biologized & 260 & 259 & 232 & 232 & 242 & & \\
\hline & Computational & 260 & 259 & 240 & 235 & 243 & & \\
\hline \multirow{4}{*}{ Surface tillage, $10-12 \mathrm{~cm}$} & Control & 240 & 239 & 220 & 194 & 203 & \multirow{4}{*}{235} & \\
\hline & Recommended & 241 & 240 & 229 & 220 & 228 & & \\
\hline & Biologized & 255 & 254 & 231 & 236 & 241 & & \\
\hline & Computational & 255 & 254 & 239 & 230 & 241 & & \\
\hline \multicolumn{2}{|c|}{$\mathrm{C}, \mathrm{NDS}_{05}=14.2$} & 254 & 252 & 234 & 222 & 230 & \multicolumn{2}{|c|}{$\mathrm{NDS}_{05}=34.8$} \\
\hline
\end{tabular}

\section{Effect of fertilizer systems, techniques and methods of tillage} on the yield $\left(t \cdot h^{-1}\right)$ of winter wheat

Table 5

\begin{tabular}{|c|c|c|c|c|c|}
\hline \multirow[b]{2}{*}{$\begin{array}{c}\text { Techniques and methods of } \\
\text { tillage, A }\end{array}$} & \multicolumn{4}{|c|}{ Fertilizersystem,B } & \multirow[b]{2}{*}{$\mathrm{A}, \mathrm{NDS}_{05}=0.11$} \\
\hline & $\begin{array}{l}\overline{0} \\
\stackrel{\Xi}{0} \\
0\end{array}$ &  & 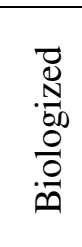 & 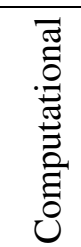 & \\
\hline Moldboard method, $20-22 \mathrm{~cm}$ & 3.78 & 5.46 & 5.09 & 6.01 & 5.09 \\
\hline Combined method, $20-22 \mathrm{~cm}$ & 3.70 & 4.95 & 4.84 & 5.58 & 5.02 \\
\hline Surface tillage, $10-12 \mathrm{~cm}$ & 3.51 & 4.68 & 4.50 & 5.13 & 4.46 \\
\hline $\mathrm{B}, \mathrm{NDS}_{05}=0.35$ & 3.66 & 5.03 & 4.81 & 5.57 & $\mathrm{NDS}_{05}=0.46$ \\
\hline
\end{tabular}

The maximum yield of winter wheat $\left(6.01 \mathrm{t} \cdot \mathrm{ha}^{-1}\right)$ was obtained by introducing a calculated dose of fertilizer $\left(\mathrm{N}_{120} \mathrm{P}_{75} \mathrm{~K}_{24}\right)$ against the background of the moldboard soil tillagemethod, which is slightly higher than the values on the combined method $\left(0.07 \mathrm{t} \cdot \mathrm{ha}^{-1}\right)$. 
Fertilizer systems had a positive effect on the grain quality of winter wheat, increasing compared to the control: gluten content - by 3.4-9.3\%, glassiness - by 10.0-23.2\%, protein content - by 1.91$3.98 \%$. On the fertilized variants, the grain corresponded to all quality indices III, on the control variant IV and VI classes (Table 6).

Table 6

\section{Effect of fertilizer systems, techniques and methods of tillage on the grain quality of winter wheat}

\begin{tabular}{|l|l|c|c|c|c|}
\hline $\begin{array}{c}\text { Techniques and } \\
\text { methods of tillage, A }\end{array}$ & $\begin{array}{c}\text { Fertilizersyste } \\
\mathrm{m}, \mathrm{B}\end{array}$ & $\begin{array}{c}\text { Glutencont } \\
\text { ent, \% }\end{array}$ & Vitreousness, \% & $\begin{array}{c}\text { Glutenstraini } \\
\text { ndicator }\end{array}$ & $\begin{array}{c}\text { Protein, } \\
\%\end{array}$ \\
\hline \multirow{3}{*}{$\begin{array}{l}\text { Moldboard method, } \\
20-22 \mathrm{~cm}\end{array}$} & Control & 19.1 & 45.0 & 77 & 10.41 \\
\cline { 2 - 6 } & Recommended & 24.5 & 57.1 & 74 & 12.50 \\
\cline { 2 - 6 } & Biologized & 26.9 & 55.0 & 74 & 12.32 \\
\cline { 2 - 6 } & Computational & 28.4 & 65.1 & 60 & 12.51 \\
\hline \multirow{3}{*}{$\begin{array}{l}\text { Combined method, } \\
20-22 \mathrm{~cm}\end{array}$} & Control & 17.9 & 41.1 & 80 & 9.01 \\
\cline { 2 - 6 } & Recommended & 23.8 & 53.7 & 77 & 12.33 \\
\cline { 2 - 6 } & Biologized & 21.3 & 51.1 & 75 & 12.18 \\
\cline { 2 - 6 } & Computational & 25.3 & 63.3 & 62 & 12.99 \\
\hline \multirow{3}{*}{$\begin{array}{l}\text { Surface tillage, 10- } \\
12 \mathrm{~cm}\end{array}$} & Control & 17.1 & 40.9 & 82 & 9.19 \\
\cline { 2 - 6 } & Recommended & 23.4 & 52.9 & 77 & 12.23 \\
\cline { 2 - 6 } & Biologized & 20.7 & 50.2 & 63 & 12.15 \\
\cline { 2 - 6 } & Computational & 23.6 & 64.1 & 63 & 12.92 \\
\hline
\end{tabular}

The maximum values of the grain quality indicators were obtained on the variants using the moldboard soil tillage method.

\section{Conclusions}

1. The maximum content of mineral nitrogen in the $0-20 \mathrm{~cm}$ layer of leached chernozem during the growing season of winter wheat was obtained using the moldboard soil tillage method $24.9 \mathrm{mg} \cdot \mathrm{kg}^{-1}$, which is significantly higher $\left(2.6\right.$ and $\left.4.8 \mathrm{mg} \cdot \mathrm{kg}^{-1}\right)$ than with the combined method and surface tillage. Fertilizer systems significantly increased the concentration of mineral nitrogen as compared with the control - by $2.2-8.4 \mathrm{mg} \cdot \mathrm{kg}^{-1}$.

2. The maximum content of mobile phosphorus, $22.2 \mathrm{mg} \cdot \mathrm{kg}^{-1}$, was noted on the variants using the moldboard soil tillage method. The use of fertilizers significantly increased the average elemental content in the $0-20 \mathrm{~cm}$ soil layer as compared with the control by $2.2-9.7 \mathrm{mg} \cdot \mathrm{kg}^{-1}$ soil.

3. On the variants with the use of the moldboard soil tillage method, on average, by experience, the maximum content of exchangeable potassium, $243 \mathrm{mg} \cdot \mathrm{kg}^{-1}$ of soil, was noted. The use of fertilizers increased the concentration of the element relative to the control by $13-26 \mathrm{mg} \cdot \mathrm{kg}^{-1}$ of soil throughout the growing season of winter wheat.

4. All the fertilizer systems studied in the experiment significantly increased the yield of winter wheat, and the difference relative to the control was: on the moldboard method $-1.31-2.23 \mathrm{t} \cdot \mathrm{ha}^{-1}$, combined - 1.14-1.88 $\mathrm{t} \cdot \mathrm{ha}^{-1}$, surface treatment $-0.99-1.62 \mathrm{t} \cdot \mathrm{ha}^{-1}$. The maximum yield of winter wheat $\left(6.01 \mathrm{t} \cdot \mathrm{ha}^{-1}\right)$ was obtained by introducing a calculated dose of fertilizer $\left(\mathrm{N}_{120} \mathrm{P}_{75} \mathrm{~K}_{24}\right)$ against the background of the moldboard soil tillage method.

5. Fertilizer systems had a positive effect on the grain quality of winter wheat, increasing compared to the control: gluten content - by 3.4-9.3\%, glassiness - by 10.0-23.2 \%, protein content - by $1.91-3.98 \%$. On the fertilized variants, the grain corresponded to all quality indices III, on the control variant IV and VI classes.

\section{References}

[1] Dromantienè R., Pranckietienè I., Šidlauskas G., Pranckietis V. Changes in technological properties of common wheat (Triticum aestivum L.) grain as influenced by amino acid fertilizers. Zemdirbyste-Agriculture, vol. 100, No. 1, 2013, pp. 57-62. 
[2] Esaulko A.N., Salenko T.F., Sigida M.S., Korostylev S.A., Golosnoy E.V. Agrochemical Principles of Targeting Winter Wheat Yield on Leached Chernozem Stavropol Elevation. Biosciences Biotechnology Research Asia, April 2015, vol. 12 (1), pp. 301-309.

[3] Trukhachev, V.I., Sklyarov, I.Y., Sklyarova, Y.M., Gorlov, S.M., Volkogonova, A.V., Monitoring of efficiency of Russian agricultural enterprises functioning and reserves for their sustainable development. Montenegrin Journal of Economics, vol. 14(3), 2018. pp. 95-108.

[4] Tskhovrebov, V.S., Faizova V.I., Mar'in A.N., Novikov A.A., Nikiforova A.M. Changing in ammonifiers of virgin land and black-earth ploughland to Central Ciscaucasia. Research Journal of Pharmaceutical, Biological and Chemical Sciences, 2016, vol. 7 (4), pp. 2174-2177.

[5] Tskhovrebov, V.S., Faizova V.I., Mar'in A.N., Kalugin D.V., Novikov A.A. Document Changing population by aerobic nitrogen-fixing bacteria in natural and anthropogenically transformed chernozems biogeocenoses Central Ciscaucasia. Source of the Document Research Journal of Pharmaceutical, Biological and Chemical Sciences, 2016, vol. 7 (4), pp. 2178-2182.

[6] Vlasova O.I., Perederieva V.M., Volters I.A., Drepa E.B., Danilets E.A. Forecrop - as an element of organic farming in the cultivation of winter wheat in the central Pre-Caucasus. Research Journal of Pharmaceutical, Biological and Chemical Sciences, 2018, vol. 9, no. 6, pp. 1272-1276.

[7] Volters I.A., Vlasova O.I., Perederieva V.M., Trubacheva L.V., Tuturzhans L.V. Influence of traditional technology and direct sowing the winter wheat on agrophysical factors of fertility the dark chestnut soils// Research Journal of Pharmaceutical, Biological and Chemical Sciences, 2018, vol. 9, no 4, pp. 718-726.

[8] Fursova A.Yu.Influence of fertilizer systems and methods of tillage on the conditions of formation of winter wheat productivity after the predecessor of peas on leached Chernozem. Polythematic network electronic scientific journal of Kuban state agrarian University,No.105, 2015, pp. 1-13.

[9] Dospekhov B. A. Methodology of field experiment. Fifth edition. Moscow: Agropromizdat, 1985. $-351 \mathrm{p}$. 